\title{
AŞAĞI SALAT HÖYÜĞÜ ZOOARKEOLOJİ ÇALIŞMALARI
}

\author{
ZOOARCHAEOLOGICAL STUDY OF AŞAĞI SALAT MOUND
}

DOI:10.17755/esosder.71974

\author{
Okşan BAŞOĞLU ${ }^{1}$ \\ Cesur PEHLEVAN ${ }^{2}$
}

$\ddot{\mathbf{O} z}$

Diyarbakır İli, Bismil İlçesi, Yukarı Salat Beldesi'nin 3 km güneyinde yer alan Aşağı Salat Höyüğü, Dicle Nehri'nin ve Salat Çayı'nın kesiştiği noktanın 2 km doğusuna konumlanmıştır. Aşağı Salat Höyüğü Kazıları, Diyarbakır Müze Müdürlüğü Başkanlığı ve Gazi Üniversitesi Arkeoloji Bölümü öğretim üyesi Prof. Dr. Süleyman Yücel Şenyurt bilimsel başkanlığı altında 2000-2002 yılları arasında üç dönem ve 2009-2010 yılları arasında iki dönem olarak gerçekleştirilmiştir. Yapılan kazı çalışmaları sonucu Kalkolitik, Erken Tunç Çağı I, MÖ I. binyıl (Yeni Asur Dönemi) ve Ortaçağ’a ait 9 kültür katı tespit edilmiştir. Hayvan kemikleri Eski Tunç Çağı, Yeni Asur Dönemi ve Orta Çağ tabakalarına ait mezarlardan ele geçmiştir. Faunayı oluşturan hayvan kemikleri üzerinde aile ve cins/tür sınıflandırılması yapılmıştır. Kemikler üzerinde yapılan incelemeler tanımlanabilen cinsıtürlerin memeli sınıfına ait olduğunu göstermektedir. Faunanın tamamına yakın bölümü evcil memelilerden oluşmakta, çoğunluk sığırlardan meydana gelmektedir. Hayvan kemiklerinin mezar alanlarından ele geçmesi, burada sunu-adak ritüelleri ve cenaze-ölü kültü ile ilgili ritüellerinin gerçekleştirildiğini düşündürmektedir.

Anahtar Kelimeler: Erken Tunç, Yeni Asur, Roma Dönemi, Zooarkeoloji, Fauna, Tarım ve Hayvancılık.

\begin{abstract}
Absract
Aşağı Salat Mound that is at $3 \mathrm{~km}$. south of Yukarı Salat which is a town in Diyarbakır/ Bismil is located at 2 $\mathrm{km}$. east of the intersection of Dicle River and Salat Stream. Aşağ Salat Mound excavations are done in three stages between the years 2000-2002 and in two stages between the years 2009-2010 under the presidency of Directorate of Diyarbakır Museum and with the scientific responsibility of Prof. Dr. Süleyman Yücel Şenyurt, who is a member in the Department of Archaeology in Gazi University. As a result, 9 different layers dated to Chalcolithic Period, Early Bronze Age I, 1st Millennium BC (Neo Assyrian Empire) and Middle Age. Findings are discovered from the burials in Early Bronze Age I, 1st Millennium BC (Neo Assyrian Empire) and Middle Age layers. Genus/species classification are made on the animal bones constituting the fauna. The analysis shows that bones identifiable to genus lspecies belongs to the class of mammals. Fauna consists of domesticated mammals by a majority of cattle (Bos taurus). The discovery of animal bones from burial area suggests that an offering-sacrifice ritual and burial ceremony was performed.
\end{abstract}

Keywords: Early Bronze Age, Neo Assyrian, Roman Period, Zooarcheaology, Fauna, Agriculture and Livestock.

\footnotetext{
1 Doç. Dr. Okşan Başoğlu, Gazi Üniversitesi, Edebiyat Fakültesi, Arkeoloji Bölümü, Teknikokullar, oksanbasoglu@gmail.com

${ }^{2}$ Doç. Dr., Yüzüncü Yıl Üniversitesi, Edebiyat Fakültesi, Antropoloji Bölümü, cesur_pehlevan@yahoo.com
} 


\section{GİRIȘ}

Zooarkeoloji, arkeolojik kayıtlardan ele geçen hayvan kemiklerinin incelenmesi yoluyla arkeoloji bilimine katkıda bulunan bir disiplindir. Bulunan hayvan kalıntılarının izin verdiği ölçüde eski insan ve çevre uyumunu ortaya koymaya çalışır (Klein \& Cruze-Uribe 1984; 1). Zooarkeolojinin amacı insan ve yaşadığı çevredeki hayvan grupları arasında kurulan ilişkiyi araştırmak ve dolayısıyla ekoloji-kültür ilişkisini anlamaya çalışmaktır. Zooarkeoloji çalışmaları sonucu, eski çağlarda uygulanan genel diyet, yararlanılan hayvan türleri, evcilleştirme, avcıllk, çiftçilik ve hayvan ekonomisi gibi konular hakkında bilgiler elde edilebilmektedir (Reitz 2010). Tarihsel süreç boyunca çevresel koşulların ekonomik yapı ve şekillenme üzerindeki etkileri ortaya konulabilmektedir. Başka bir deyişle zooarkeoloji, insanı yaşadığ arkeologların tablolarında eksik kalan bazı renk ve çizgileri yerine yerleştirmektir (Atıcı 1998; 233).

\section{AŞAĞI SALAT HÖYÜĞ̈̈}

Diyarbakır İli, Bismil İlçesi, Yukarı Salat Beldesi’nin 3 km güneyinde yer alan Aşağı Salat Höyügü, Dicle Nehri'nin ve Salat Çayı'nın kesiştiği noktanın 2 km doğusuna konumlanmıştır. Höyük üzerinde bugün Yukarı Salat Beldesi'ne bağlı Aşağı Salat Mahallesi bulunmaktadır. Yayvan bir höyük olan Aşağı Salat Höyüğü, Dicle Nehri kenarında, $3.5 \mathrm{~m}$ yükseklikteki holosen sekisi üzerine kurulmuştur. Höyük, Dicle Nehri ve kolları tarafından beslenen bir arazidedir. Aşağı Salat Mahallesi'nin altında kalmış olan höyük yaklaşık 150 x $100 \mathrm{~m}$ boyutlarındadır. Bugünkü nehir seviyesinin yaklaşı $3 \mathrm{~m}$ yukarısındaki teras üzerinde bulunan küçük boyuttaki höyügün kültür dolgusu, modern yerleşmenin orta kesimlerinde yaklaşık $5 \mathrm{~m}$ yüksekliktedir. Dicle Nehri'nin taşkınları nedeniyle höyügün güney kesimi tahrip olmuştur. Aşağ1 Salat yerleşmesi, çağdaş yerleşme ve Dicle Nehri tarafından tahrip edilmektedir ve güneydoğu kesiminin büyük bölümü su ile aşınmıştır (http://www.tayproject.org).

Yapılan kazı çalışmaları sonucu Kalkolitik, Erken Tunç Çağı I, MÖ I. binyıl (Yeni Asur Dönemi) ve Ortaçağ'a ait 9 kültür katı tespit edilmiştir (Şenyurt 2002; 445). Bunlardan en eski kültür katı Kalkolitik Dönem'e tarihlenmiştir. Bu katın üzerinde ise mimari kalıntılarının yoğunlaştığı Erken Tunç Çağı I'e (MÖ 3000-2700) ait kültür katları bulunmuştur. Höyügün batı kesiminde ise Erken Tunç Çağı I'e ait mezarlar ortaya çıkarılmıştır. En üstte ise MÖ I. binyıla ait kat ve İslami Dönem'e tarihlenen Ortaçağ katı bulunmaktadır. Erken Tunç Çağı I ile MÖ I. binyıl arasında höyükte bir yerleşim kesintisi söz konusudur. Arkeolojik sonuçlara göre, höyükteki kültür toprağının ve kültür katlarının kalın olmaması ve çoğu zaman belirgin bir mimari sunmaması, burada kısa süreli, kesintili yerleşmeleri düşündürmektedir (Şenyurt 2002; 445-447). Yapılan jeoarkeolojik araştırmalara göre, Kalkolitik Çağ'da iklim kurak olduğu ve dolayısıyla Dicle Nehri’nde taşkınlar söz konusu olmadığı için o dönemin insanları akarsuyun kenarında ve fazla yüksek olmayan bu alana yerleşmişlerdir. Erken Tunç Çağı I'in sonuna doğru iklim yavaş yavaş nemlenmeye başlamış ve ilk taşkınlar baş göstermiştir. Bulgular, Dicle kenarındaki alanların ETÇ I ile MÖ I. binyıl arasında akarsu taşkın tehlikesinden dolayı yerleşilemeyecek halde olduğunu ve önceden kurulan yerleşmelerin de bu dönemde terk edildiğini göstermektedir. Bu taşkınlara bağlı olarak höyükteki yerleşmelerin kısa dönemli olduğu ve belirli sürelerle kesintiye uğradığı tespit edilmiştir (Doğan 2002; 134,136).

Aşağı Salat Höyüğü Kazıları, Diyarbakır Müze Müdürlüğü Başkanlığı ve Gazi Üniversitesi Arkeoloji Bölümü öğretim üyesi Prof. Dr. Süleyman Yücel Şenyurt bilimsel başkanlığı altında 20002002 yılları arasında üç dönem ve 2009-2010 yılları arasında iki dönem olarak gerçekleştirilmiştir. Hayvan kemikleri Eski Tunç Çağı, Yeni Asur Dönemi ve Orta Çağ tabakalarına ait mezarlardan ele geçmiştir.

\section{MATERYAL VE METOT}

Çalışmanın materyalini Diyarbakır\Aşağı Salat Höyüğü kazı çalışmaları kapsamında ele geçen hayvan kemikleri oluşturmaktadır. Küçük parçalar halinde ve korunma derecesi kötü durumda olarak ele geçen kemikler gerekli zooarkeolojik analizler gerçekleştirilmek üzere laboratuvar ortamında temizlenmiş, onarılmıştır. İlk aşamada onarılan kemikler tanımlanabilir ve tanımlanamaz olarak sınıflandırıldıktan sonra birbirine benzeyen kemikler takson farkı gözetmeden bir araya getirilmiştir. Daha sonra, tanımlanabilen her bir buluntunun hangi kemiğe (femur, humerus vb), kemiğin hangi 
bölümüne (proksimal, distal, gövde vb), hangi tarafa (să̆, sol) ait olduğu tespit edilmiştir. İkinci aşamada bir araya getirilen aynı kemikler üzerinde morfolojik özelliklerine göre aile, mümkünse cins/tür bazında saptamalar yapılmaya çalışılmıştır (Payne 1969; 295, Payne 1985; 142, Schmid 1972, Hesse ve Wapnish 1985; 6, Hilson 1992, Hillson 2005; 7, Davis 1995; 23-47, O’Connor 2004; 36, Klein ve Cruze-Uribe 1984; 21-24, 46-47). Yaşlandırma için epifizyal yaşlandırma (Schmind 1972) ve diş sürmesi (Hilson 2005; 207-255, Davis 1995; 39) yöntemleri kullanılmıştır. Ayrıca kasaplık, yanık ve işleme izleri incelenmiştir (Hesse ve Wapnish 1985; 20-56, Davis 1995; 91, O'Connor 2004; 45, Klein ve Cruze-Uribe 1984). Bunların dışında, hangi cins ve türe ait olduğu belirlenemeyen ancak boyut açısından ele alınabilecek durumda olan memeli kemikleri büyük, orta ve küçük boy olarak değerlendirilmiştir. Burada büyük boy memeliler at, eşek ya da sığır boyutlarındaki canlıları; orta boy memeliler koyun ve keçi boyutlarındaki canlıları, küçük boy memeliler kedi ve köpek boyutlarındaki canlıları ifade etmektedir. Bunun yanı sıra tanımlanabilen aile, tür ve cinslerin fauna içinde dağılımı ortaya konmuştur. Tüm bu bilgiler ışığında Aşağı Salat Höyüğü'nün zooarkeolojik yapısı belirlenmeye çalışılmıştır. Arkeolojik yerleşimlerde tespit edilen türler ve onların morfolojik özellikleri belli ekolojik nişlere işaret ettikleri için arkeolojik yerleşimlerde geçimin sağlandığı çevrenin kapsamı ve sınırları hakkında önemli ipuçları vermektedir( Uerpmann 1996, Çakırlar 2008; 255). Bunun yanı sıra ekolojik ortamın genel özelliklerini ortaya koyabilmektedir.

\section{BULGULAR}

Dicle Nehri yanına konumlanan Aşağı Salat Höyüğü'ndeki kemikler sık sık nehir taşkınlarına maruz kaldığı için iyi korunamamış ve çok parçalı halde ele geçmiştir. Höyükten ele geçen ve çalışma materyalimizi oluşturan 1267 kemik zooarkeolojik açıdan ele alınmıştır. Faunayı oluşturan 1267 kemikten 460 kemik (\% 36.30) üzerinde cins/tür sınıflandırılması yapılmıştır. 131 kemik (\% 10.33) büyük boy, 158 kemik (\% 12.47) orta boy, 22 kemik (\% 1.73) küçük boy olarak belirlenmiştir. Geri kalan 496 kemik (\% 39.14) tanımlanamamıştır. Tanımlanamayan parçalar göz önünde tutularak sağlıklı sonuç alınamayacağı düşünüldüğünden minimum birey sayısı belirlenmemiştir. Tanımlanabilen 460 kemikten yola çıkılarak oluşturan Aşağı Salat Höyüğü faunası Tablo 1 de gösterilmiştir. Tanımlanamayan kemikler içerisinde yoğunluğu uzun kemik parçaları ve kaburga parçaları oluşturmaktadır. Kemikler üzerinde herhangi bir kasaplık ve yanık izine rastlanmamıştır. Kemiklerin korunma durumunun kötü olması tafonomik analiz yapmayı engellemiş̧tir.

Aşağı Salat Höyüğü hayvan kemikleri üzerinde yapılan faunal analizler sonucu tanımlanabilen aile ve cinsltürlerin genellikle memeli sınıfina ait bireylerden oluştuğu saptanmıştır. Çalışmada az sayıda etçil kemikleri tanımlanabilmiştir. İncelenen örneklerin çoğunluğu otçullara aittir. Bununla birlikte nadir olarak Aves (kuş) ve Pisces (balık) kemikleri de ele geçmiştir. Az sayıda ele geçen küçük memeli kemiklerine de rastlanmıştır. Yeni Asur Dönemi'ne ait tabakalardan kunduz dişleri de bunlardan biridir. Ancak küçük memeli hayvanlara ait kemikler değerlendirmeye alınmamıştır. Elde edilen verilere göre fauna Ovis|Capra, Bos taurus, Equus sp., Sus scorfa, ve Canis famillaris'e ait kemiklerden oluşmaktadır. Aşağı Salat Höyüğü faunasının dağılımı Grafik 1'de yer almaktadır. Faunanın \% 38'ini sığırlar oluşturmaktadır. Sığırların hemen ardından koyun ve keçiler (\% 29) gelmektedir. At/eşek ve domuzlar ise \% 14'lük bir oranla faunada temsil edilmektedirler. Geyikler oranı $\% 2$ olarak belirlenmiştir. Etçiller faunanın sadece \%3'lük dilimini oluşturmaktadır. 
Tablo 1: Aşağı Salat Höyüğü Faunası

\begin{tabular}{|l|l|l|}
\hline FAUNA & LATINCE ADI & YEREL ADLANDIRMA \\
\hline 1. OTÇULLAR & & \\
\hline a. Evcil Toynaklılar & $\begin{array}{l}\text { Bos taurus } \\
\text { Equus } s p . \\
\text { Ovis } s p . \\
\text { Capra } s p .\end{array}$ & $\begin{array}{l}\text { Evcil sığır } \\
\text { At, eşek, katır } \\
\text { Koyun } \\
\text { Keçi }\end{array}$ \\
\hline b. Yabani Toynaklılar & $\begin{array}{l}\text { Cervus } s p . \\
\text { Sus scrofa }\end{array}$ & Geyik \\
\hline 2. ETÇİLLER & Canis famillaris & Köpek \\
\hline 3. KEMİRGENLER & Castor & Kunduz \\
\hline 4. KUŞLAR & Aves & Kuş, tavuk \\
\hline
\end{tabular}

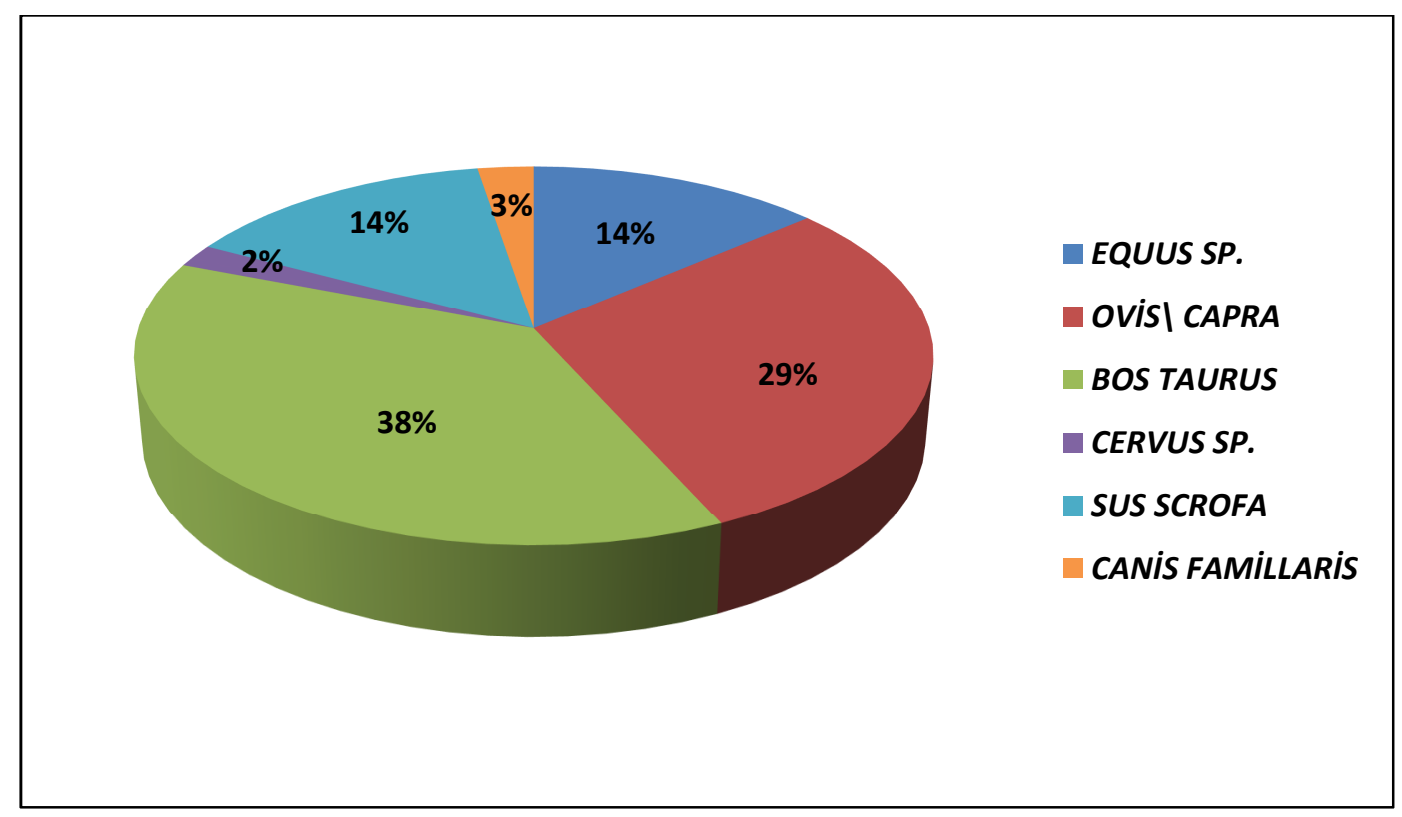

\section{Grafik 1: Aşağı Salat Höyüğü Faunasının Dağılımı.}

Eski Tunç Çağı, Yeni Asur Çağı ve Orta Çağ'a ait nekropol alanlarından ele geçen fauna ve materyal sayısı Tablo 2'de verilmiştir. Kemiklerin iskeletin hangi bölümünü oluşturdukları belirlenmiştir (Grafik 2). En çok ele geçen kemikler izole dişler ve mandibula kemikleridir. Aşağı Salat Höyüğ̈̈'nde sığırlar; humerus, ulna, radius, femur, tibia, metapodium, phalanx, costa ve vertebra yoğunluğu açısından diğerlerinden farklılık göstermektedir. Fauna içinde en çok izole diş buluntusu da sığırlara aittir. Koyun ve keçilere ait kemiklerin dağılımı incelendiğinde en çok mandibula, vertebra ve astragalus örneklerinin bu grup içinde olduğu görülmektedir. At ve eşeklerde ise izole dişler, mandibula, vertebra ve costaların baskın olduğu görülmektedir. Domuzlar, ağırlıklı olarak mandibula, maxilla ve izole dişlerle temsil edilmektedir. Genel olarak bakıldığında domuz, koyun ve keçilerin kafatası ve alt çenelerinin, sığırların ön ve arka üyelerinin ve sırt bölgesinin tercih edildiği söylenebilir. Yapısal özellikleri bakımından doğada en iyi şekilde korunan dişler en çok ele geçen materyalleri oluşturmaktadır ve ikinci sırayı mandibula örnekleri almaktadır (Grafik 2). 
Tablo 2: Aşağı Salat Höyüğü Memeli Faunası ve Materyal Sayısı.

\begin{tabular}{|c|c|c|c|c|c|c|}
\hline \multirow{2}{*}{$\begin{array}{c}\text { MATERYAL } \\
\text { Cranium }\end{array}$} & $\begin{array}{c}\text { EQUU } \\
\text { S SP. }\end{array}$ & $\begin{array}{c}\text { OVIS } \\
\text { CAPRA }\end{array}$ & $\begin{array}{c}\text { BOS } \\
\text { TAURUS }\end{array}$ & $\begin{array}{c}\text { CERVUS } \\
\text { SP. }\end{array}$ & $\begin{array}{c}\text { SUS } \\
\text { SCROFA }\end{array}$ & $\begin{array}{c}\text { CANIS } \\
\text { FAMILLARIS }\end{array}$ \\
\hline Korn & - & - & - & - & - & - \\
\hline Maxilla+diș & 2 & 2 & - & - & - & - \\
\hline Mandibula+diş & 6 & 36 & 10 & 2 & 17 & - \\
\hline Vertebra & 7 & 12 & 11 & - & - & - \\
\hline Costa & 7 & - & 15 & - & - & - \\
\hline Scapula & 1 & 8 & 2 & - & - & 1 \\
\hline Humerus & 2 & 9 & 14 & - & - & 2 \\
\hline Radius-Ulna & 4 & 4 & 4 & - & - & - \\
\hline Phalanx & 4 & 8 & 26 & 2 & 1 & - \\
\hline Coxa & - & 2 & - & - & - & - \\
\hline Femur & - & - & 4 & - & - & 2 \\
\hline Tibia & - & 8 & 7 & 1 & - & 1 \\
\hline Metapodium & - & 5 & 12 & - & - & - \\
\hline Astragalus & - & 15 & 6 & - & - & - \\
\hline Calcaneus & - & 2 & 2 & 1 & - & - \\
\hline İzole Diş & 29 & 18 & 60 & 1 & 31 & 1 \\
\hline
\end{tabular}

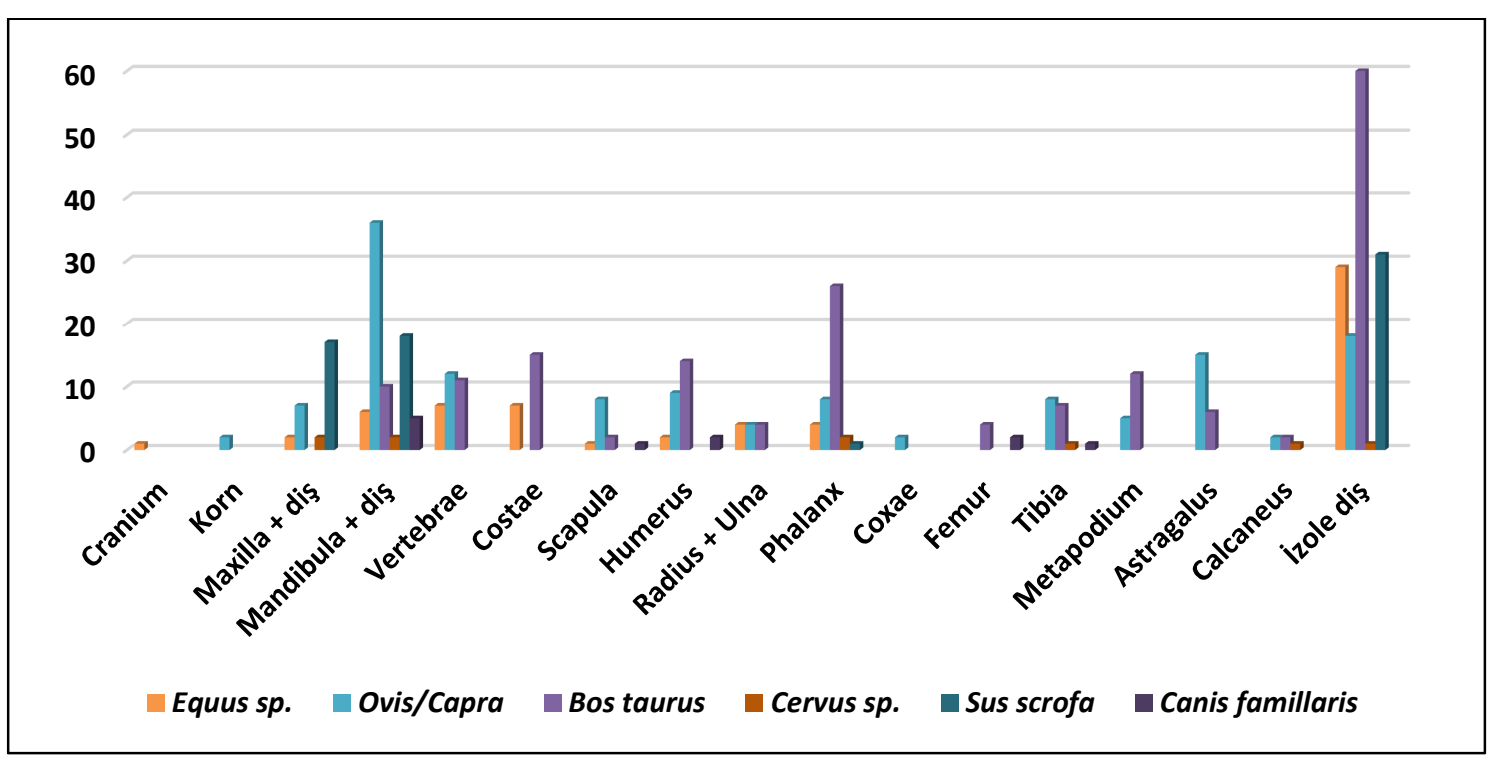

Grafik 2: Aşağı Salat Höyüğü Kemik Materyal Dağılımı.

Koyun, keçi ve sığırların büyük bir kısmı erişkin bireylere aittir. Çok küçük kısmı kuzu, oğlak, buzağı diyebileceğimiz genç bireylere aittir. Evcil hayvan topluluklarında bu tip yaş dağılımı kentleşme sürecini işaret etmektedir (Wapnish ve Hesse 1988; 81). Çünkü yetişsin bireylerin çokluğu et üretiminden ziyade süt ve yün üretimi gibi hem tüketime hem de pazarlamaya yönelik ikincil ürünlere ağırlık verildiğini göstermektedir.

Tanımlanabilmiş kemiklere dayanarak aile ve cins/tür dağılımına bakıldığında, fauna içerisinde evcil hayvan türü fazladır (Tablo 1). Yapılan analizde az sayıda da olsa yabani hayvan olarak geyik kemiklerine rastlanması avcılık faaliyetlerinin devam ettiğini göstermektedir. Geyik ve benzeri hayvan populasyonları, bu dönemlerde Anadolu' da geniş alanlara yayılmışlardır (Uerpmann 1987; 173). Avcılığın çok önemli bir geçim kaynağı oluşturmamakla beraber çevrede yapıldığı geyik 
kemiklerinden anlaşılmaktadır. Bu durum avcılığa nazaran hayvancılığın beslenme ekonomisinde çok daha önemli bir yer teşkil ettiği ortaya koymaktadır.

Birey sayısı belirlenememekle birlikte materyallerin hayvan cinsleri üzerindeki dağılımlarına bakıldığında sığır gibi büyükbaş hayvanlarda yoğunluk olduğu gözlenmiştir (Grafik 1). Bu durum büyükbaş hayvancılığın Aşağı Salat Höyüğü insanları için önemli bir yer tuttuğunu göstermektedir. Bu da doğrudan etten alınan protein açısından sığırın önemli hayvan olduğunu ortaya koymaktadır. Sığır ve at gibi su ihtiyacı koyun ve keçilere göre daha fazla olan hayvanların yoğunluğu Aşağı Salat yerleşmesinin bu tür hayvancılığa elverişli oldukça sulak bir ortama sahip olduğunu göstermektedir. Yerleşim bölgelerinin sahip olduğu yüksek yağış oranları büyükbaş hayvancılığın artışını sağlamaktadır. Anadolu'da çevre kuraklaştıkça büyükbaş hayvancılık azalmaktadır (Omar ve Erkman 2012; 95). Höyüğün Dicle Nehri'nin kıyısında yer alması bu ekolojik ortama uygun hayvancılığın gelişmesine neden olmuştur.

Arkeolojik yerleşimlerde evcil domuzların olması ortamın sulak olmasına bağlansa da, yapılan araştırmalar Yakın Doğu'da yaban domuzların hem sulak hem de kıraç ortamlara uyum sağlayabildiğini göstermiştir (Falconer 1995; 399, Hesse 1986; 17, Wapnish ve Hesse 1988; 81, Upperman 1996, Çakırlar 2008; 259). Buradan yola çıkarak, Aşağı Salat Höyügü̈nde domuz kemiklerinin bulunması coğrafi ortamın yanı sıra sosyoekonomik koşullara da bağlanabilir. Her ne kadar koyun/keçi ve sığırlar kadar ekonomik olmasa da bu hayvanlar yerleşmede yetiştirilmiş olabilirler.

Dönemlere göre fauna dağılımına bakıldığında yabani hayvanların daha çok Eski Tunç Çağı tabakalarında yer aldığı görülmektedir. Domuzlar sıklıkla Eski Tunç ve Yeni Asur tabakalarında rastlanmıştır. Eski Tunç ve Yeni Asur dönemlerinde ekonomik yapı büyük ölçüde domuz ve koyun/keçilere dayanmaktadır. Hemen hemen tüm Anadolu'da ekonomik ürünler koyun ve keçiye endekslidir. İklimsel dalgalanmalardan büyükbaş hayvanlar kadar etkilenmemektedirler. $\mathrm{Bu}$ dönemlerde mevsimlik bir yerleşme olarak kullanılan Aşağı Salat yerleşmesinde küçükbaş hayvanların büyükbaş hayvanlara göre yoğunlaşması koyun ve keçilerin daha kolay denetlenebilir, değiş tokuş yapılabilir en önemlisi ekonomik hayvanlar olmasına bağlanabilir. Zooarkeolojik araştırmalar, Erken ve Orta Tunç Çağı dönemlerinde kentlerdeki sosyoekonomik yapının gelişmesinin hayvan ekonomisini etkilese de asıl etkenin coğrafik bölge ve iklime bağlı olduğunu göstermektedir (Silibolatlaz ve Satar 2012; 95).

Sığır ve atlar Orta Çağ'da en yoğun biçimde bulunmuştur. Bu yoğunluk höyüğün sahip olduğu coğrafik özelliklerin yanı sıra, Tunç Çağı'ndan itibaren değişen ve gelişen sosyo-ekonomik süreçlere de bağlanabilir. Ticari ilişkilerin gelişmesiyle beraber büyükbaş hayvanlar yük taşıma, alet yapımı gibi farklı amaçlar için de kullanılmaya başlanmıştır. Avcılık devam etmekle birlikte evcilleştirme ve hayvancılık tam anlamıyla gerçekleştirilmiştir. Helen-Roma-Bizans dönemlerinde özellikle büyükbaş hayvancılık gelişmiştir (Silibolatlaz ve Satar 2012; 87). Aşağı Salat faunası bu durumu yansıtmaktadır.

Tablo 3: Dönemlere Göre Așağı Salat Höyüğ̈̈ Memeli Faunası.

\begin{tabular}{|c|c|c|}
\hline Erken Tunç Çağı & Yeni Asur Dönemi & Orta Çağ \\
\hline Cervus sp. & Bos taurus & Bos taurus \\
\hline Ovis/Capra & Ovis/Capra & Ovis/Capra \\
\hline Sus scrofa & Sus scrofa & Sus scrofa \\
\hline Equus $s p$. & Equus $s p$. & Equus sp. \\
\hline & Castor & Canis familiaris \\
\hline
\end{tabular}

Az sayıda ele geçen etçil kemiklerine rağmen, fauna içerisinde Ortaçağ tabakalarından bulunan önemli buluntulardan biri de iyi korunmuş durumda olan tam bir köpek iskeletidir (Fotoğraf 1). Eski çağlardan beri köpeğin önemli bir kurban hayvanı olduğu ve ölümle ilişkilendirildiği bilinmektedir. Mezarlardan ele geçen köpek iskeletleri bu durumu yansıtmaktadır. Tarihin ilk dönemlerinden itibaren cesetlerin bir köpek eşliğinde gömülmesi köpeklerin koruyucu vasfina vurgu yapmaktadır. Hitit döneminde Anadolu'da benzer uygulamalar tespit edilmiştir. Hattuşaş'ta ele geçen mezarlarda bulunan köpek kemikleri, insanın öbür dünyaya sadık bir yoldaşla gitme dileğinin ifadesi 
olarak kabul edilmiştir (Florioti 2014; 59). Mezarlardaki at veya köpek gömüleri ölü insanın öbür dünyaya yolculuğunda eşlik etme anlamı taşıdığı düşünülmektedir (Vermeule 1984; 61).

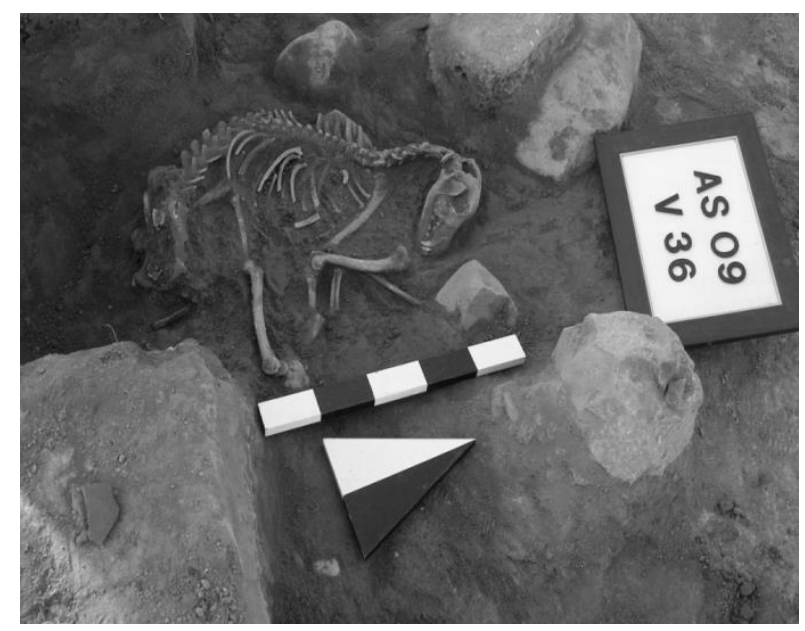

Resim 1: Ortaçă̆ tabakasından bir köpeğe ait iskelet.

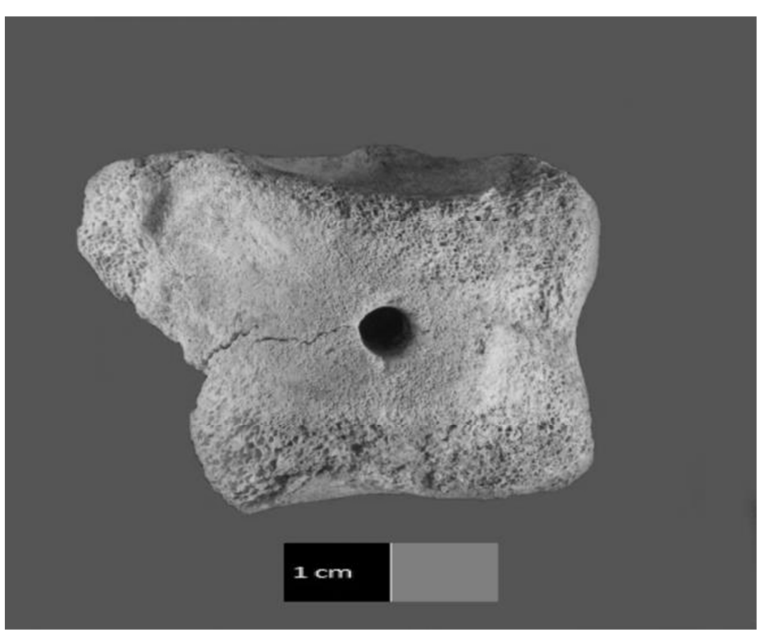

Resim 2: Bir sığıra ait astragalus

Hayvan kemikleri arasında bir sığıra ait astragalus üzerinde bilinçli olarak oluşturulmuş bir delik gözlenmiştir (Fotoğraf 2). Bu tür kemiklerin oyun ya da süs aracı olarak kullanılmış olabilecekleri düşünülmektedir (Hopkins 2003). Antik Yakın Doğu, Anadolu, Kıbrıs ve Ege'de Bronz Çağından başlayarak mezarlarda görülmeye başlanmıştır. Antik dönemde Akdeniz bölgesinde yaygın bir şekilde olarak kullanılan bu kemikler farklı işlevsel amaçlar için kullanılmışlardır (Miniti ve Peyronel 2005, 18). Bu kemiklerin kehanetlerde bulunmak işlevi yanında düzenli olarak ölüyle birlikte mezar odasına konuldukları görülmüştür. Bunların kutsal alanda depolanmaları ise adak kurbanlarının işlevsel amacına dayandırılmıştır. Efes Artemisionu'nda bulunan astralagusların adak törenlerinin artıkları olarak tespit edilmiştir (Shadler 1996; 73). Ancak yaygın olan diğer bir görüş de bir oyun malzemesi olarak insanların kullandığı aşık kemiklerinin ölülere de sunulmasıdır. $\mathrm{Bu}$ durum günümüzde hala Anadolu'nun kırsal kesimlerinde oynanan "Aşık Atma Oyunu” nun eski çağlardan beri bilinen bir oyun olduğu göstermektedir. $\mathrm{Bu}$ örnek dışında incelediğimiz diğer hayvan kemiklerinde herhangi bir tafonomik bulguya rastlanmamıştır.

Hayvan kemiklerinin yoğunlukla kült yerinden ve mezarlardan ele geçmesi burada bir cenazeölü kültü ritüelleri gerçekleştirildiğini düşündürmektedir. Literatürde de benzer sonuçlara ulaşan araştırmalar yer almaktadır (Satar ve diğ. 2006; 51). Eski Tunç Çağı ölü kültü geleneklerine göre cenaze töreni bittikten sonra bazı seremoniler yapılmaktadır. Bunlar, ölünün mezarı başında hediyelerin sunulması, kurbanların kesilmesi, çeşitli sıv1 libasyonlarının yapılması ve yemek yenmesidir (Uhri 2006; 21-23). Orta Çă̆ Roma geleneğinde cenazeden sonraki dokuzuncu günde mezar başında yemek geleneğinin bulunduğu belirtilmekte, ölü için yiyecek sunuları mezara bırakılmaktadır (Erten 2015; 20). Bu bilgiler 1şığında, mezarlardan ele geçen kemik buluntularının adak hayvanlarının ölüye sunulan parçaları ve ölü yemeği olarak yenilen hayvanlara ait kalıntılar olabileceği düşünülmektedir. Bir başka olasılık ise mezarlardaki hayvan kemiği buluntularının yukarıda bahsi geçtiği gibi ölüye eşlik etmesi amacıyla birlikte gömülen hayvanlara ait olmasıdır.

\section{SONUÇ}

Çalışma materyalini oluşturan Aşağı Salat Höyüğü hayvan kemikleri, gerek nehir taşkınları gerekse yerleşim tahribatı nedenleri ile iyi korunmamıştır. Kemiklerin tanımlanmasında birinci kriter olan eklem uçları birçok materyalde kırıktır. Tanımlanabilen kemik sayısı az olmakla beraber genel zooarkeolojik yapı ve bulguların arkeolojik birimlerle ilişkileri ortaya koyma açısından önemli bilgilere ulaşılmıştır.

Kemiklerin korunma durumunun kötü olması tafonomik analiz yapmayı engellemiştir. Tespit edilen hayvanların üç tanesi genç erişkin olarak belirlenmiştir. Geri kalan bireylerin hepsi erişkindir. Erişkin bireylerin çokluğu et üretiminden ziyade süt ve yün üretimi gibi hem tüketime hem de 
pazarlamaya yönelik ikincil ürünlere ağırlık verildiğini göstermektedir ve kentleşme sürecini işaret etmektedir. Erken dönemlerden ele geçen geyik kemikleri avcılık faaliyetlerinin devam ettiğini göstermekle birlikte fauna çoğunlukla evcil hayvanlardan oluşmuştur. Eski Tunç ve Yeni Asur dönemlerinde küçükbaş hayvanlar daha çok tercih edilmiştir. Orta Çağ'da ise sığır kemikleri önemli bir çoğunluğa ulaşmıştır. Bu dönemde koyun, keçi, sığır ve köpek varlığı ekonomi faaliyetlerinde hayvancılığın önemli bir yere sahip olduğunu göstermektedir. Eski Tunç ve Yeni Asur dönemlerinde ekonomik olarak önemli bir hayvan olan domuz Orta Çağ'da azalmıştır. Bu azalma besin kaynaklarının değişmesi, sosyokültürel yapı gibi çeşitli nedenlerden ileri gelmiş olabileceği düşünülmektedir. Aşağı Salat faunası, ait olduğu dönemlerin sosyoekonomik, kültürel ve coğrafi özelliklerini yansıtmıştır.

İnsanlık tarihinin büyük bir bölümünü içeren prehistorik dönemler boyunca insanın yaşam mücadelesinde avcılık ve av hayvanları ne kadar önemli ise bugün kazılardan ele geçirilen hayvan kemikleri ve kalıntılarının araştııılması da aynı derecede önemlidir. Anadolu'da yapılan birçok arkeolojik kazı sonucunda ele geçen fauna analizleri ekonomik yapının şekillenmesinde hayvansal kaynakların rolünü ortaya koyma açısından önemlidir. Bu noktada zooarkeolojik çalışmaların gerekliliğinin ve arkeoloji bilimine katkılarının anlaşılması ve bu alanda yapılan araştırmaların hızla arttırılıp geliştirilmesi gerekmektedir (Atıcı 1998; 246 ).

Teşekkür: Destek ve yardımları için Prof. Dr. S. Yücel Şenyurt’a teşekkür ederim.

\section{KAYNAKÇA}

Atıc1, L. (1998). Zooarkeoloji: Amacı, Yöntemleri ve Arkeolojideki Önemi. Ankara Üniversitesi $\quad$ Dil ve Tarih-Coğrafya Fakültesi Dergisi, Cilt 38, Sayı 1.2, 230-246.

Davis, S.J.M. (1995). The Archaeology of Animals. Yale University Press, New Haven and London.

Doğan, U. (2002). Aşağı Salat Höyüğü'nün Jeoarkeolojisi. 18. Arkeometri Sonuçları Toplantısı, Cilt I, 131-141.

Çakırlar, C. (2008). Aççana Höyüğü'nde Arkeozooloji Çalışmaları: 2007 Yılı Raporu. 24. Arkeometri Sonuçları Toplantısı,253-267.

Erten, E. (2015). Olba Kült Alanlarından Cam Buluntular. Selevcia ad Calycadnvm, Sayı V, 61-77.

Falconer S. E. (1995). Rural responses to early urbanism: Bronze Age household and village economy at Tell el-Hayyat, Jordan. Journal of Field Archaeology, 22(4), 399-419.

Florioti, Duymuş, H. H. (2014). Eski Kültürlerde Köpeğin Algılanışı:Eski Mezopotamya Örneği. Ankara Üniversitesi Tarih Araştırmaları Dergisi, Cilt33, Sayı 55 (Mart), 45-70.

Hesse, B. and Wapnish, P. (1985). Animal Bone Archaeology From Objectives to Analysis. Washington.

Hesse, B. (1986). Animal use at Tel Migne-Ekron in the Bronze Age and Iron Age. Bulletin of the American Schools of Oriental Research, 264, 17-27.

Hillson, S. (1992) Mammal Bones and Teeth: An Introductry Guide to Methods of Identification. Institute of Archaeology, London.

Hillson, S. (2005). Teeth. Cambridge University Press, New York.

Hopkins, L. (2003) Archaeology at the Northeast Anatolian Frontier. VI. An Ethnoarchaeological Study of Sos Höyük and Yiğittaşı Village, Louvain.

Klein, R.G., \& Cruz-Uribe, K. (1984). The Analysis of Animal Bones from Archaeologieal Sites. Prehistoric Archaeology and Ecology series, The University of Chicago Press, Chicago and London.

Miniti. C. and Peyronel L. (2005). Symbolic or Functional Astragali from Tell Mardikh-Elba (Syria). Archaeofauna, 14,7-26.

O'connor, T. (2004). The Archaeology of Animal Bone. Sutton Publishing. Great Britain. 
Omar, L. VE erkman, A. C. (2012). Anadolu ve Yukarı Mezopotamya Tunç Çağı Yerleşkelerinin Faunal Analizi. Güleç, E., Özer, İ., Koca Özer, B., Sağır, M. (Ed.) Biyolojik Antropoloji, A. Ü. DTCF Yayınları, Ankara.

Payne, S. (1969). Metrical Distinction Between Sheep and Goat Metacarpals. In; Ucko P. And Dimbleby G. (eds) The Domestication and Exploitation of Plants and Animals, 295-305. London, Duckworth.

Payne, P. (1985). Morphological Distinctions Between the Mandibular Cheek Teeth of Young Sheep, Ovis and Goats, Capra. Journal of Archaeological Science, 12, 139-147.

Reitz, J. E. (2010). Zooarchaeology. Second Edition, Cambridge University Press, New York.

Satar, Z., Baykara, İ., Güleç, E., Açıkkol, A. (2006). Altıntepe/Tuşpa Nekropolü Faunasının Arkeozoolojik Analizi. 21. Arkeometri Sonuçları Toplantısı, 51-63, Ankara.

Schadler, U. (1996). “Spielen mit Astragalen”, Archaologischer Anzeiger ,1, 61-73.

Silibolatlaz Baykara., D., ve Satar., Z. (2010). Anadolu Zooarkeolji Çalışmaları. Güleç, E., Özer, İ., Koca Özer, B., Sağır, M. (Ed.) Biyolojik Antropoloji, A. Ü. DTCF Yayınları, Ankara.

Schmid, E. (1972). Atlas of Animal Bones for Prehistorians, Archaeologist and Quaternary Geologists. Elsevier Publishing Company. Amsterdam.

Şenyurt, S.Y. (2002). Ilısu Barajı-Aşağı Salat 2000 Yılı Kazısı, 23. Kazı Sonuçları Toplantısı, Cilt II, 445453.

Uerpmann, H. P. (1996). Zur Ökologie des Epipaläolithikums im Vorderen Orient. In: D. Schyle \& H.-P. Uerpmann: Das Epipaläolithikum des Vorderen Orients.Beihefte zum Tübinger Atlas des Vorderen Orients. Reihe B Nr., 85(2).Wiesbaden..

Uerpmann H. P. (1987). The Ancient Distribution of Ungulate Mammals in the Middle East - Fauna and Archaeological Sites in Southwest Asia and Northeast Africa. Beihefte zum Tübinger Atlas des Vorderen Orients, Reihe A (Naturwissenschaften) Band, 27, 173.

Uhri, A. (2006). Batı Anadolu Erken Tunç Çă̆ı Ölü Gömme Gelenekleri (Ege Üniversitesi Sosyal Bilimler Enstitüsü Arkeoloji Anabilim Dalı Yayınlanmamış Doktora Tezi). İzmir.

Vermeule E. (1984). Aspects of Death in Early Greek Art and Poetry. University, of California Press, Berkeley, Los Angeles, London.

Wapnish P.\& Hesse B. (1988). Urbanization and the organization of animal production at Tell Jemmeh in the Middle Bronze Age Levant. Journal of Near Eastern Studie, 47(2), 81-94.

Wapnish, P. (1987). Faunal Remains. In: McCann, A. M., The Roman Port and Fishery of Cosa. Princeton University Press, 315-317.

Wapnish, P., Hesse, B. \& Ogilvy, A. (1977). The 1974 Collection of Faunal Remains from Tel Dan. Bulletin of the American Schools of Oriental Research, 227, 35-63.

\section{İnternet Kaynakları}

http://www.tayproject.org/2016. 